\title{
Effect of Surface Structure on Electrical Performance of Industrial Diamond Wire Sawing Multicrystalline Si Solar Cells
}

\author{
Shaoliang Wang, ${ }^{1}$ Xianfang Gou, ${ }^{2,3}$ Su Zhou $\mathbb{D}^{2,4}$ Junlin Huang, ${ }^{2,4}$ Qingsong Huang, \\ Jialiang Qiu, ${ }^{2}$ Zheng $\mathrm{Xu}\left(\mathbb{1}^{1},{ }^{1}\right.$ and Honglie Shen ${ }^{4}$ \\ ${ }^{1}$ Institute of Optoelectronics Technology, Beijing Jiaotong University, Beijing 100044, China \\ ${ }^{2}$ CECEP Solar Energy Technology (Zhenjiang) Co. Ltd., Zhenjiang 212132, China \\ ${ }^{3}$ Beijing University of Technology, Beijing 100124, China \\ ${ }^{4}$ Nanjing University of Aeronautics and Astronautics, Nanjing 211106, China
}

Correspondence should be addressed to Su Zhou; zhousu2003@hotmail.com and Zheng Xu; zhengxu@bjtu.edu.cn

Received 22 November 2017; Revised 19 February 2018; Accepted 7 March 2018; Published 2 May 2018

Academic Editor: Germà Garcia-Belmonte

Copyright $\odot 2018$ Shaoliang Wang et al. This is an open access article distributed under the Creative Commons Attribution License, which permits unrestricted use, distribution, and reproduction in any medium, provided the original work is properly cited.

We report industrial fabrication of different kinds of nanostructured multicrystalline silicon solar cells via normal acid texturing, reactive ion etching (RIE), and metal-assisted chemical etching (MACE) processes on diamond wire sawing wafer. The effect of different surface structure on reflectivity, lifetime, and electrical performance was systematically studied in this paper. The difference between industrial acid, RIE, and MACE textured multicrystalline silicon solar cells to our knowledge has not been investigated previously. The resulting efficiency indicates that low reflectivity surface structure with the size of $0.2-0.8 \mu \mathrm{m}$ via RIE and MACE process do not always lead to low lifetime compared with acid texturing process. Both RIE and MACE process is promising candidate for high efficiency processes for future industrial diamond wire sawing multicrystalline silicon solar cells.

\section{Introduction}

Recently, diamond wire sawing technique on multicrystalline silicon wafer grew up at a very high speed due to costeffectiveness compared to traditional slurry sawing process $[1,2]$. It was demonstrated that diamond wire sawing (DWS) has several superiorities over multiwire slurry sawing (MWSS), that is, higher slicing speed, less saw damage layer, better environmental friendship, and potential for cutting thinner wafers $[3,4]$. However, diamond wire sawing brings a big texturing problem due to the surface with less saw damage layer and less start point for normal acid texturing [5]. For mass production, there are now three main types of industrial techniques for fabricating DWS mc-Si solar cells: acid texturing with additive [6], reactive ion etching (RIE) [7], and metal-catalyzed chemical etching (MACE) [8-10].

In this work, the comparison between different process and the effect of different surface structure on reflectivity, lifetime, and electrical performance was systematically studied. We also demonstrate that DWS mc-Si solar cells can achieve average efficiency as high as $19.05 \%$ and $18.86 \%$ by RIE and MACE, respectively.

\section{Experimental}

The acid texturing, RIE, and MACE processes presented in this work are applied in the following solar cell fabrication process using industrial production machine:

Acid texturing for DWS $\mathrm{mc}$ silicon wafers by etching in $\mathrm{HF} / \mathrm{HNO}_{3} / \mathrm{H}_{2} \mathrm{O}$ /additive solution ( $49 \mathrm{wt} \% \mathrm{HF}: 65 \mathrm{wt} \%$ $\mathrm{HNO}_{3}: \mathrm{H}_{2} \mathrm{O}=1: 2: 1.2$ by volume, $10^{\circ} \mathrm{C}$ ) and subsequent cleaning in $\mathrm{KOH}$ solution and $\mathrm{HF} / \mathrm{HCl}$ solution via RENA Inline text machine. Acid texturing for MWSS mc silicon wafers as reference by etching in $\mathrm{HF} / \mathrm{HNO}_{3} / \mathrm{H}_{2} \mathrm{O}$ solution ( $49 \mathrm{wt} \% \mathrm{HF}: 65 \mathrm{wt} \% \mathrm{HNO}_{3}: \mathrm{H}_{2} \mathrm{O}=1: 3: 2$ by volume, $10^{\circ} \mathrm{C}$ ) and subsequent cleaning in $\mathrm{KOH}$ solution and $\mathrm{HF} / \mathrm{HCl}$ solution via RENA Inline text machine. RIE for DWS mc silicon wafers by etching in $\mathrm{HF} / \mathrm{HNO}_{3} / \mathrm{H}_{2} \mathrm{O}$ solution ( $49 \mathrm{wt} \% \mathrm{HF}$ : $65 \mathrm{wt} \% \mathrm{HNO}_{3}: \mathrm{H}_{2} \mathrm{O}=1: 3: 2$ by volume, $10^{\circ} \mathrm{C}$ ) to remove saw damage layer, maskless $\mathrm{RIE}$ in $\mathrm{SF}_{6} / \mathrm{O}_{2} / \mathrm{Cl}_{2}$ plasma with 


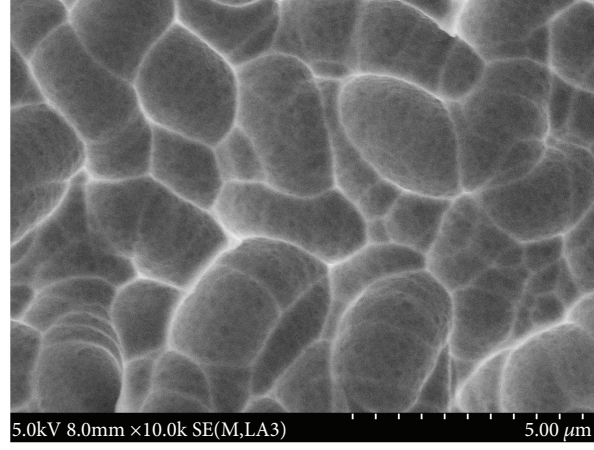

(a) Acid-etched MWSS mc-Si wafer

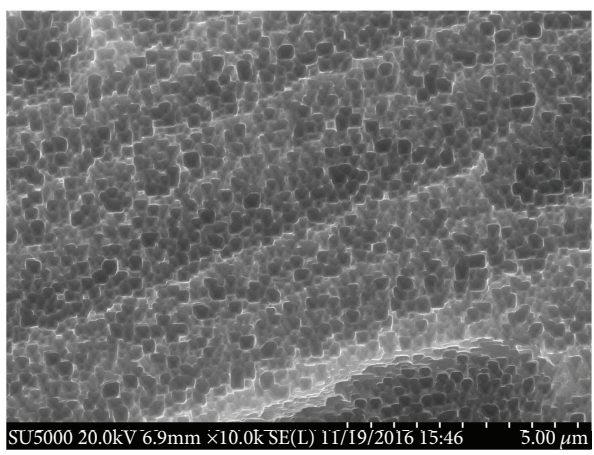

(c) RIE DWS mc-Si wafer

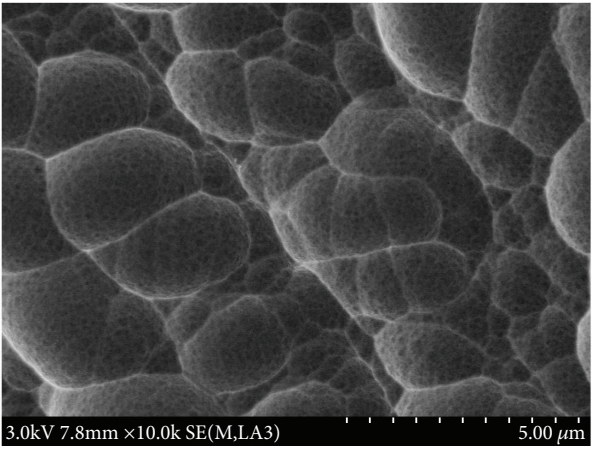

(b) Acid-etched DWS mc-Si wafer

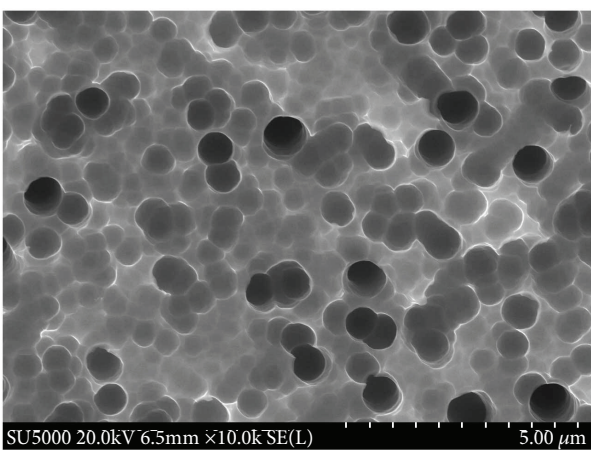

(d) MACE DWS mc-Si wafer

FiguRE 1: SEM pictures of different surface structures.

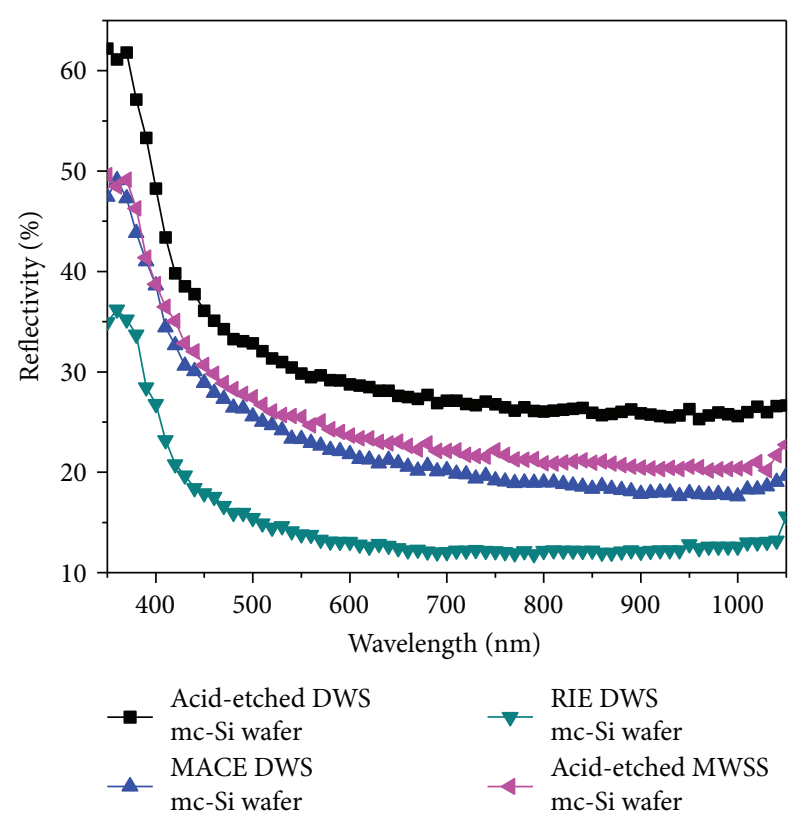

FIGURE 2: Reflectivity versus wavelength curves of wafers with different microstructures.

13.56 $\mathrm{MHz}$ radiofrequency using Belight system, and subsequent etching in $\mathrm{HF} / \mathrm{NH}_{4} \mathrm{~F} / \mathrm{H}_{2} \mathrm{O}_{2}$ solution. MACE for DWS mc silicon wafers by etching in $\mathrm{HF} / \mathrm{HNO}_{3} / \mathrm{H}_{2} \mathrm{O} / \mathrm{AgNO}_{3}$ solution (49 wt\% HF: $65 \mathrm{wt} \% \mathrm{HNO} 3: \mathrm{H} 2 \mathrm{O}=1: 2: 2$ by volume, $25^{\circ} \mathrm{C}$ ), cleaning in hot $\mathrm{HNO}_{3}$ solution and subsequent etching in $\mathrm{HF} / \mathrm{HNO}_{3} / \mathrm{H}_{2} \mathrm{O}$ solution. The etch depth of all texturing process are about $2.9 \mu \mathrm{m}$ per each wafer side.

Emitter formation using a tube furnace from CT Systems with liquid $\mathrm{POCl}_{3}$ as dopant source at a temperature of $835^{\circ} \mathrm{C}$ and atmospheric pressure for $60 \mathrm{~min}$ in $\mathrm{O} 2$ and N2 ambient followed by edge isolation and removal of phosphor-silicate glass (PSG) using Rena tool. Plasma enhanced chemical vapor deposition (PECVD) of $80 \mathrm{~nm}$ hydrogenated amorphous silicon nitride ( $\mathrm{SiNx}: \mathrm{H})$ antireflective coating at $400^{\circ} \mathrm{C}$ using a CT tool. Screen printing of $\mathrm{Al}$ rear contact, Ag rear contact, and Ag front contact with standard paste, which was fired using a Despatch infrared fast-firing furnace, with a peak temperature set point of $925^{\circ} \mathrm{C}$ and a belt speed of $6000 \mathrm{~mm} / \mathrm{min}$.

Samples used for lifetime measurement were deposited by $\mathrm{SiN}$ on both side and fired at the same temperature as the cell. The microstructure, reflection, lifetime of minority carrier, and IV curves of the resulted mc-Si wafers or solar cells were measured by SEM (Hitachi, S4800, Japan), reflectometer (Radiation Technology D8, China), IV measurement system (Halm, Germany), and WT2000 (Sinton WCT120, USA), respectively.

\section{Results and Discussion}

3.1. Microstructure of mc-Si Wafers with Different Texture Process. Figure 1 shows the SEM pictures of different surface structures including acid etching on MWSS wafer and acid etching, RIE, and MACE on DWS wafer. Figures 1(a) and 1(b) compare the surface morphologies of acid etching on 


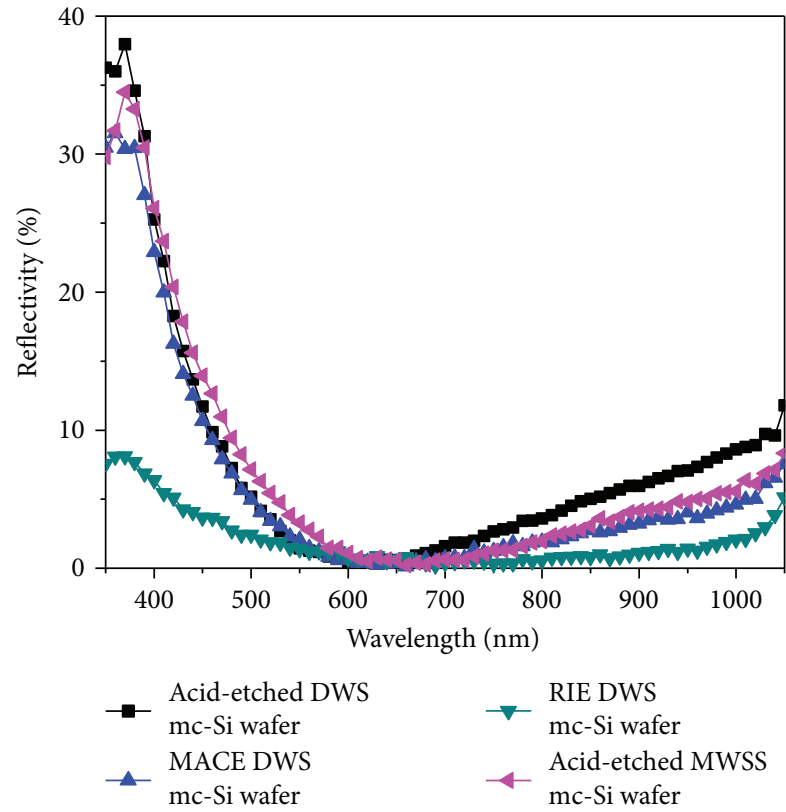

FIGURE 3: Reflectivity versus wavelength curves of SiN-deposited wafers with different microstructures.

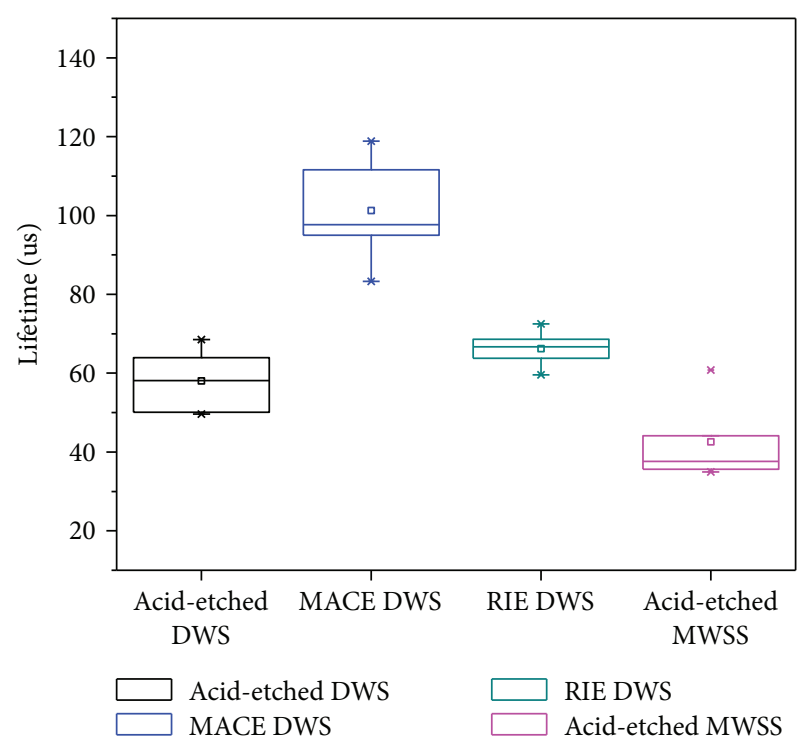

FIGURE 4: Minority carrier lifetime of wafers with different surface structures.

MWSS and DWS wafer. Obviously, the size of oval pits is quite similar and about 2-5 $\mu \mathrm{m}$. A uniform nanostructure fabricated by RIE was successfully integrated into the former etching pit on DWS wafer in Figure 1(c). The diameter of the nanostructure is in the range of $200-400 \mathrm{~nm}$. Figure 1(d) shows that uniform small round etching pits with the size of $500-800 \mathrm{~nm}$ can be obtained by MACE process on DWS wafer.

3.2. Reflectance of mc-Si Wafers and SiN-Deposited Wafer with Different Texture Process. Figure 2 shows the reflectivity
$R$ versus the wavelength (350-1050 nm) curves of wafers with different microstructures. The average reflectivity $R_{\text {ave }}$ of the acid etching DWS wafer (31.0\%) is 5.7\% higher than that of the MWSS wafer (25.3\%), while the $R_{\text {ave }}$ of RIE DWS mc-Si wafer (15.1\%) and MACE DWS mc-Si wafer (23.2\%) is $15.9 \%$ and $7.8 \%$ less than that of the acid-etched DWS mcSi wafer (31.0\%). The reflectivity difference between acidetched DWS and MWSS may be attributed to the deeper etching pit in the MWSS wafer than those of the DWS wafer because a thin amorphous silicon layer only found in the DWS wafer will prevent effective etching of the surface $[8,11]$. The size of surface structure should be responsible for the significant reflectivity reduction of RIE and MACE DWS mc-Si wafer compared to acid-etched ones.

Figure 3 shows the reflectivity $R$ versus the wavelength (350-1050 nm) curves of SiN-deposited wafers with different microstructures. The average reflectivity $R_{\text {ave }}$ of the acidetching DWS wafer $(7.7 \%)$ is $0.8 \%$ higher than that of the MWSS wafer (6.9\%), while the $R_{\text {ave }}$ of RIE DWS mc-Si wafer $(2.1 \%)$ and MACE DWS mc-Si wafer (5.8\%) is 5.6\% and $1.9 \%$ less than that of the acid-etched DWS mc-Si wafer (7.7\%).

\subsection{Minority Carrier Lifetime of $m c-S i$ Wafers with Different} Texture Process. Figure 4 shows the minority carrier lifetime of wafers with different microstructures. The average lifetime of the acid-etching DWS mc-Si wafer (58.1 us) is 15.5 us higher than that of the MWSS mc-Si wafer (42.6 us), while the $R_{\text {ave }}$ of RIE DWS mc-Si wafer (66.2 us) and MACE DWS mc-Si wafer (101.3 us) is 8.1 us and 43.2 us higher than that of the acid-etched DWS mc-Si wafer (58.1 us). The increasement of lifetime of acid-etched DWS mc-Si wafer compared to that of MWSS wafer was due to the thinner saw damage layer of DWS mc-Si wafer. It is important that even the size of surface structure decrease to several hundred nanometers, good surface passivation can still be obtained on DWS mc-Si wafer with proper process. It can be inferred that within the size of several hundred nanometers, the surface area is not the key factor to affect surface passivation. Especially for MACE process, the $\mathrm{HF} / \mathrm{HNO}_{3} / \mathrm{H}_{2} \mathrm{O}$ treatment after Ag-removal acts like "rounding" process in texturing for HIT solar cells, providing possibility to deposit high-quality passivation film [12]. Both RIE and MACE processes have the potential to optimize surface recombination velocity and reflectance simultaneously.

3.4. Electrical Parameters of mc-Si Solar Cells with Different Surface Structure. Table 1 shows electrical performance of mc-Si solar cells with different surface structure. Even with some additive to improve the reflectance of acid-etched DWS mc-Si wafer, higher reflectivity leads to lower short-circuit current density $\left(36.25 \mathrm{~mA} / \mathrm{cm}^{2}\right)$ and efficiency $(18.51 \%)$ compared to that of acid-etched MWSS mc-Si wafer $\left(36.60 \mathrm{~mA} / \mathrm{cm}^{2}\right.$ and $\left.18.60 \%\right)$. Both RIE and MACE processes show significant current improvement compared to acid-etching process on DWS mc-Si solar cells due to the lower reflectance. Comparing RIE DWS with MACE DWS mc-Si solar cells, the RIE process shows higher $J_{\text {sc }}$ and MACE process shows higher $V_{\mathrm{oc}}$ which is in accord with the reflectivity and lifetime results. The average 
TABLE 1: Electrical performance of mc-Si solar cells with different surface structure.

\begin{tabular}{lcccc}
\hline & $V_{\mathrm{oc}} / \mathrm{mV}$ & $J_{\mathrm{sc}} /\left(\mathrm{mA} / \mathrm{cm}^{2}\right)$ & $\mathrm{FF} / \%$ & $\eta / \%$ \\
\hline Acid-etched MWSS & $635.1 \pm 1.5$ & $36.60 \pm 0.10$ & $80.00 \pm 0.16$ & $18.60 \pm 0.09$ \\
Acid-etched DWS & $636.2 \pm 1.3$ & $36.25 \pm 0.07$ & $80.25 \pm 0.15$ & $18.51 \pm 0.08$ \\
RIE DWS & $635.6 \pm 1.9$ & $37.48 \pm 0.08$ & $79.96 \pm 0.13$ & $19.05 \pm 0.10$ \\
MACE DWS & $636.9 \pm 2.8$ & $36.89 \pm 0.13$ & $80.28 \pm 0.12$ & $18.86 \pm 0.16$ \\
\hline
\end{tabular}

efficiency and open-circuit voltage of RIE (19.05\%) and MACE (18.86\%) also demonstrate their potential to achieve higher performance and the possibility to be mainstream texturing process for DWS mc-Si solar cells.

\section{Conclusion}

In summary, $19.05 \%$ and $18.86 \%$ efficiency DWS mc-Si solar cells with uniform nanotexture have been fabricated through RIE and MACE processes on an industrial production line. The results confirmed that both RIE and MACE process technique can provide an effective texture for DWS mc-Si solar cells. Because of the significant improvement of lighttrapping ability on RIE and surface passivation ability on MACE DWS mc-Si solar cells, the $J_{\text {sc }}$ of RIE DWS mc-Si solar cell is $1.23 \mathrm{~mA} / \mathrm{cm}^{2}$ higher and the $V_{\text {oc }}$ of MACE DWS mc-Si solar cell is $0.7 \mathrm{mV}$ higher than that of an acid-etched one. Those results demonstrate the biggest obstacle for industrial wide spread of DWS mc-Si wafer has been removed by the application of RIE or MACE process and this will benefit for high efficiency and low cost of the PV industry.

\section{Conflicts of Interest}

The authors declare that there is no conflict of interest regarding the publication of this paper.

\section{Acknowledgments}

The authors express their thanks to the National Natural Science Foundation of China under Grant no. 61575019; the Fundamental Research Funds for the Central Universities with Grant no. 2017RC034, no. 2017RC015, and no. 2017JBZ105; the Doctoral Program of Higher Education no. 20130009130001; and Jiangsu Planned Projects for Postdoctoral Research Funds (1701072B).

\section{References}

[1] N. Watanabe, Y. Kondo, D. Ide, T. Matsuki, H. Takato, and I. Sakata, "Characterization of polycrystalline silicon wafers for solar cells sliced with novel fixed-abrasive wire," Progress in Photovoltaics: Research and Applications, vol. 18, no. 7, pp. 485-490, 2010.

[2] $\mathrm{H} . \mathrm{Wu}$, "Wire sawing technology: a state-of-the-art review," Precision Engineering, vol. 43, pp. 1-9, 2016.

[3] C. Yang, H. Wu, S. Melkote, and S. Danyluk, "Comparative analysis of fracture strength of slurry and diamond wire sawn multicrystalline silicon solar wafers," Advanced Engineering Materials, vol. 15, no. 5, pp. 358-365, 2013.
[4] A. Kumar, S. Kaminski, S. N. Melkote, and C. Arcona, "Effect of wear of diamond wire on surface morphology, roughness and subsurface damage of silicon wafers," Wear, vol. 364365, pp. 163-168, 2016.

[5] B. Meinel, T. Koschwitz, C. Blocks, and J. Acker, "Comparison of diamond wire cut and silicon carbide slurry processed silicon wafer surfaces after acidic texturisation," Materials Science in Semiconductor Processing, vol. 26, pp. 93-100, 2014.

[6] M. Lippold, F. Buchholz, C. Gondek, F. Honeit, E. Wefringhaus, and E. Kroke, "Texturing of SiC-slurry and diamond wire sawn silicon wafers by $\mathrm{HF}-\mathrm{HNO}_{3}-\mathrm{H}_{2} \mathrm{SO}_{4}$ mixtures," Solar Energy Materials and Solar Cells, vol. 127, pp. 104-110, 2014.

[7] J. Yoo, G. Yu, and J. Yi, "Large-area multicrystalline silicon solar cell fabrication using reactive ion etching (RIE)," Solar Energy Materials and Solar Cells, vol. 95, no. 1, pp. 2-6, 2011.

[8] F. Cao, K. Chen, J. Zhang et al., "Next-generation multicrystalline silicon solar cells: diamond-wire sawing, nanotexture and high efficiency," Solar Energy Materials and Solar Cells, vol. 141, pp. 132-138, 2015.

[9] Z. G. Huang, X. X. Lin, Y. Zeng et al., “One-step-MACE nano/ microstructures for high-efficient large-size multicrystalline Si solar cells," Solar Energy Materials and Solar Cells, vol. 143, pp. 302-310, 2015.

[10] Y. Jiang, H. Shen, T. Pu et al., "High efficiency multi-crystalline silicon solar cell with inverted pyramid nanostructure," Solar Energy, vol. 142, pp. 91-96, 2017.

[11] A. Bidiville, K. Wasmer, R. Kraft, and C. Ballif, "Diamond wire-sawn silicon wafers - from the lab to the cell production," in 24th European Photovoltaic Solar Energy Conference, pp. 1400-1405, Hamburg, Germany, 2009.

[12] G. Li, Y. Zhou, and F. Liu, "Influence of textured c-Si surface morphology on the interfacial properties of heterojunction silicon solar cells," Journal of Non-Crystalline Solids, vol. 358, no. 17, pp. 2223-2226, 2012. 

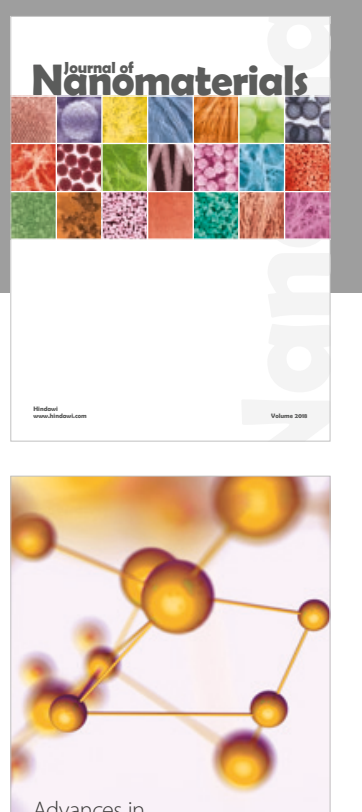

Physical Chemistry
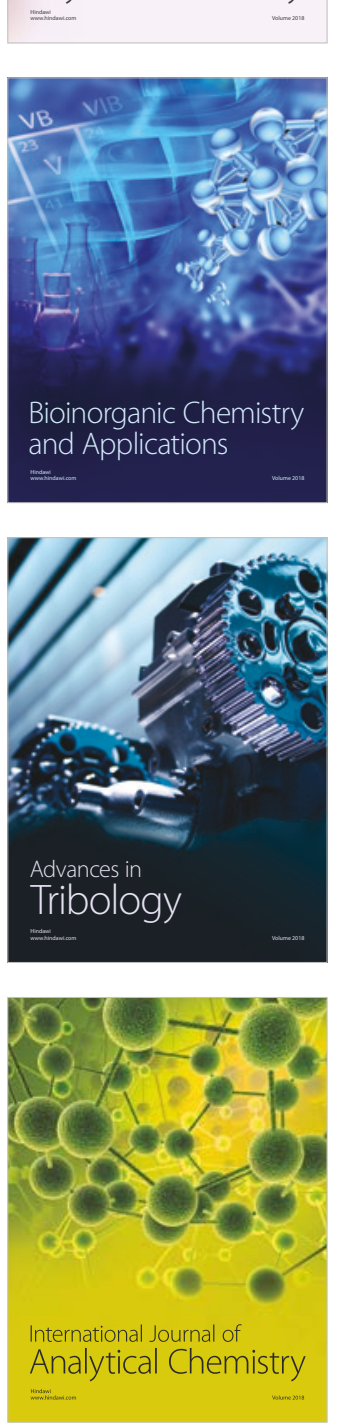

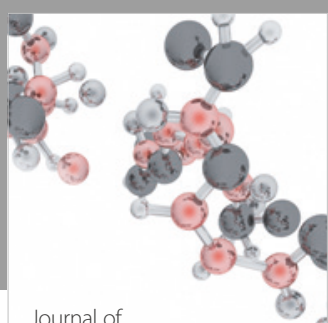

Analytical Methods

in Chemistry

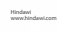

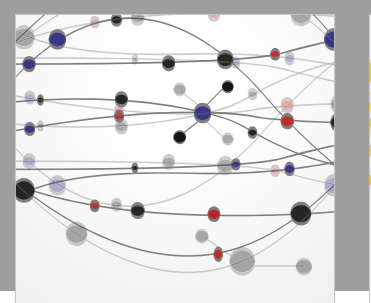

The Scientific World Journal

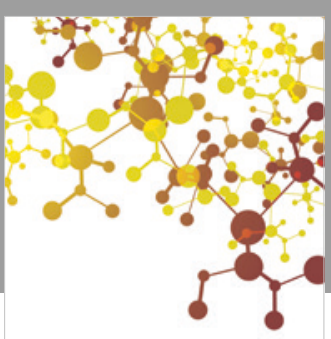

Journal of

Applied Chemistry
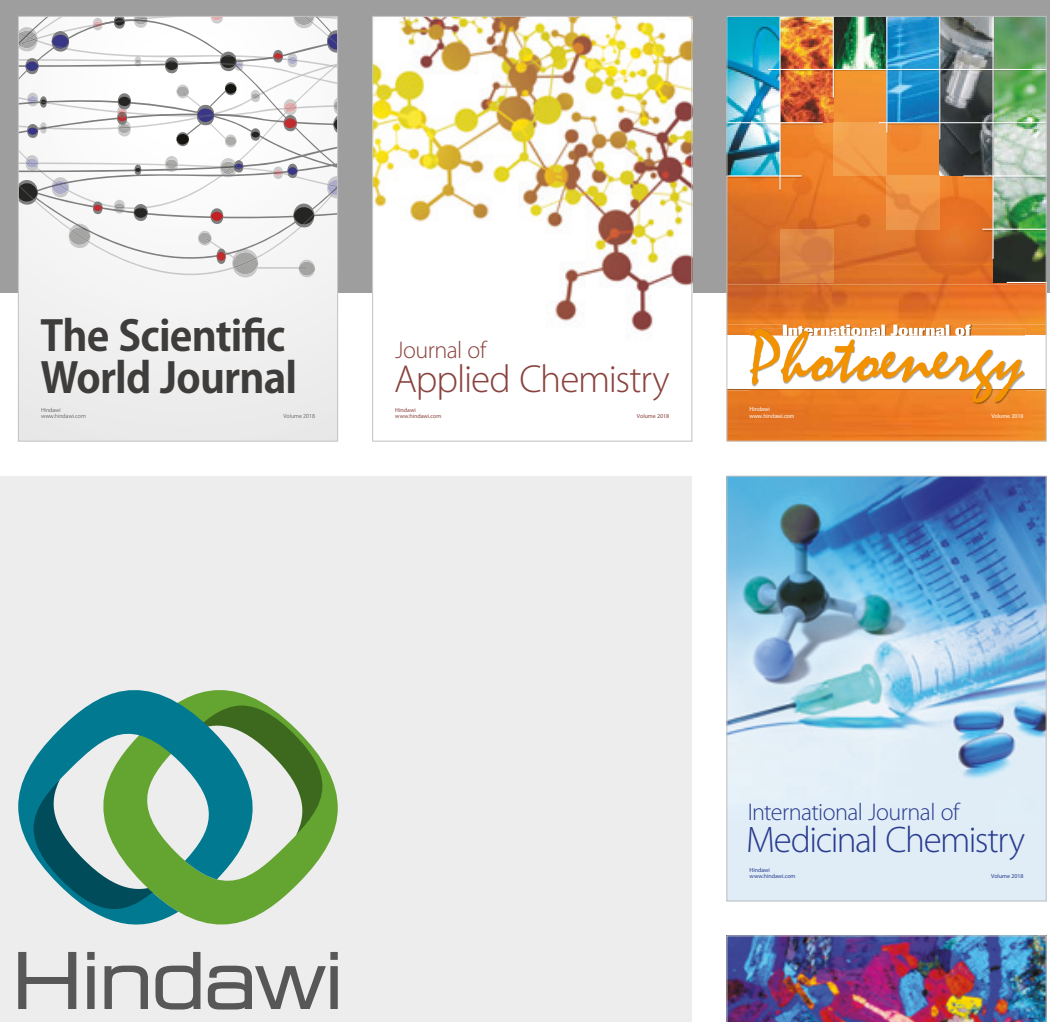

Submit your manuscripts at

www.hindawi.com
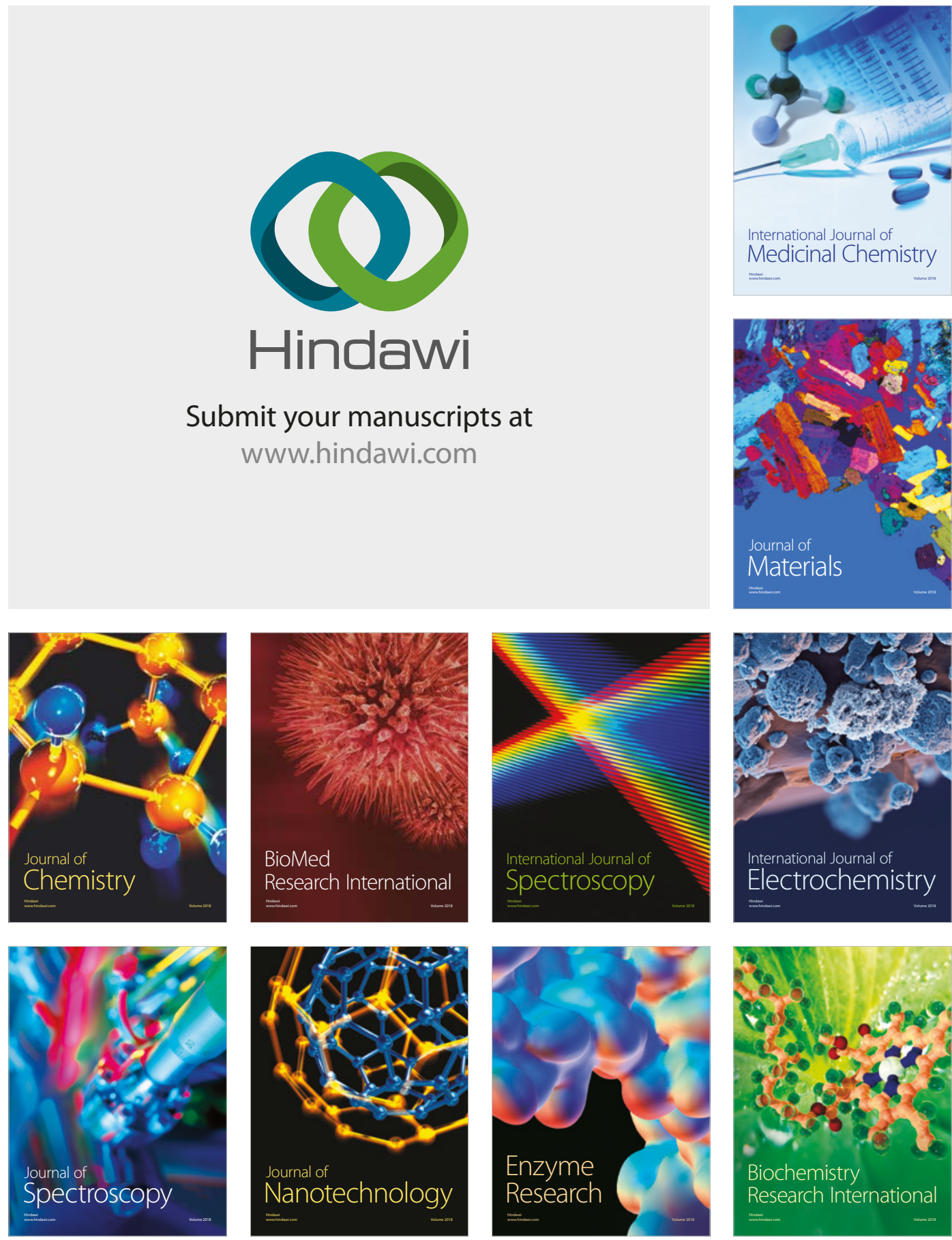
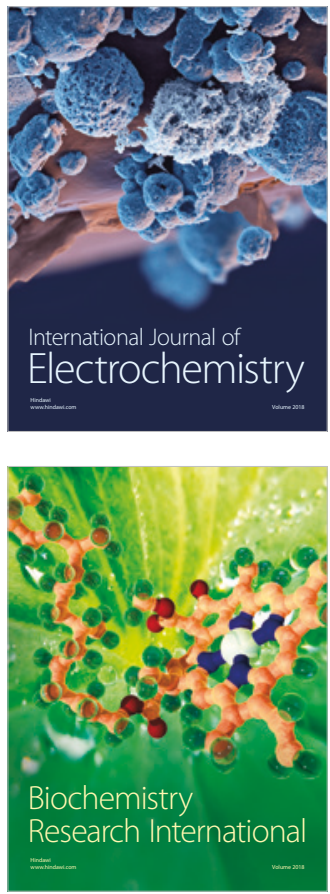